\title{
PROFIL SISWA RETARDASI DALAM MEMBACA PUISI (STUDI KASUS)
}

\section{THE PROFIL OF RETARDATED STUDENTS IN READING POETRY (CASE STUDY)}

\author{
Eni Nurhayati ${ }^{*}$, Budhi Rahayu sri Wulan', Satria Wahyu Ramadhan ${ }^{3}$ \\ PGSD STKIP PGRI Sidoarjo, Indonesia ${ }^{1,2,3}$ \\ eninurhayati188@gmail.com ${ }^{1}$, brswulan@gmail.com $^{2}$, \\ wahyusatriasatria183@gmail.com ${ }^{3}$ \\ *penulis korespondensi
}

\begin{tabular}{ll}
\hline Info Artikel & ABSTRAK \\
\hline Sejarah artikel: & Penelitian ini bertujuan memaparkan profil siswa retardasi dalam membaca \\
Diterima: & puisi. Siswa retardasi memiliki kesulitan tersendiri dalam membaca. Dalam \\
7 November 2020 & hal ini khusus pada keterampilan membaca puisi. Siswa retardasi memiliki \\
Direvisi: & kesulitan membaca namun tidak sampai tahap disleksia. Fokus pada \\
23 Desember 2020 & penelitian ini ialah tentang aktivitas pemerolehan vokal, diftong, konsonan, \\
Disetujui: & dan pemerolehan kata. Penelitian ini termasuk penelitian kualitatif jenis \\
15 Januari 2021 & studi kasus. Subyek penelitian ini adalah (VK) seorang siswa kelas 5 SD. \\
& Pengumpulan data menggunakan teknik observasi, wawancara, dan \\
Kata kunci: & dokumentasi. Tiga kriteria yang diamati yaitu, Vokal, Diftong, dan \\
Retardasi, vokal, & Konsonan yang terdapat pada fona. Vokal, Diftong, dan Konsonan, anak \\
konsonan, diftong, & hanya dapat membaca dengan vokal rendah sampai sedang saja. Yang \\
kata & kedua, anak dapat membaca diftong /ai/dan /au/ dengan benar, namun hanya \\
& pada dua suku kata saja, berbeda dengan yang mempunyai beberapa suku \\
& kata, anak tidak dapat membacanya dengan benar. Dan memenuhi beberapa \\
kriteria dalam kata. anak dapat membaca vokal /au/, /ai/, dan huruf /ng/ & dengan benar, namun hanya pada dua suku kata saja, berbeda dengan kata \\
& yang mempunyai 4 suku kata atau lebih, anak masih salah dalam membaca \\
& huruf- huruf tersebut. Pada saat anak membaca huruf /ny/ juga anak belum \\
mampu dalam membacanya dengan benar, walau hanya dua suku kata. Dan \\
pada membaca yang mempunyai pola seperti (KVK), (VKK), dan (KVKK), \\
anak juga belum mampu membacanya dengan benar.
\end{tabular}

\begin{tabular}{|c|c|}
\hline Article Info & ABSTRACT \\
\hline $\begin{array}{l}\text { Article history: } \\
\text { Received: } \\
7 \text { November } 2020 \\
\text { Revised: } \\
23 \text { December } 2020 \\
\text { Accepted: } \\
\text { 15 January } 2021 \\
\text { Keywords: } \\
\text { Retardation, } \\
\text { vowels, } \\
\text { consonants, } \\
\text { diphthongs, words }\end{array}$ & $\begin{array}{l}\text { This study aims to describe the profiles of retarded students in reading } \\
\text { poetry. Retarded students have their own difficulties in reading. In this case } \\
\text { specifically on poetry reading skills. Retarded students have reading } \\
\text { difficulties but are not at the dyslexic stage. The focus of this research is on } \\
\text { the activity of acquiring vowels, diphthongs, consonants, and word } \\
\text { acquisition. This research is qualitative case study type research. The subject } \\
\text { of this study was (VK) a 5th grade elementary student. Collecting data using } \\
\text { observation, interview, and documentation techniques. Three criteria are } \\
\text { observed, namely, Vowels, Diphthongs, and Consonants which contained in } \\
\text { phone. Vowels, Diphthongs, and Consonants, children can only read low to } \\
\text { moderate vowels. Second, children can read diphthongs /ai/ and /au/ } \\
\text { correctly, but only in two syllables, unlike those with several syllables, } \\
\text { children cannot read them correctly. Moreover, it meets several criteria in } \\
\text { the word. Children can read vowels /au/, /ai/, and letters /ng/ correctly, but } \\
\text { only in two syllables, in contrast to words that have } 4 \text { or more syllables, the } \\
\text { child is still mistaken in reading the letters. When the child reads the letter }\end{array}$ \\
\hline
\end{tabular}


/ny/, the child is not able to read it correctly, even though only two syllables. And in reading that has patterns such as (KVK), (VKK), and (KVKK), children are also not able to read them correctly.

Copyright $\odot$ 2021, Stilistika: Jurnal Pendidikan Bahasa dan Sastra DOI: http://dx.doi.org/10.30651/st.v14i1.6425

\section{PENDAHULUAN}

Keberadaan anak kesulitan belajar sekarang ini banyak dijumpai dalam setiap kelas di sekolah dasar. Kesulitan belajar yang dihadapi anak dengan anak yang lain bermacam-macam yaitu kesulitan membaca, menulis, dan berhitung. Anak yang memiliki kesulitan dalam satu atau lebih dari kesulitan belajar, biasanya memiliki nilai prestasi yang rendah terhadap mata pelajaran. Menurut Bryan dan Bryan dalam Abdurrahman (2009:204), menyatakan bahwa kesulitan belajar membaca merupakan suatu kesulitan dalam belajar segala sesuatu yang berkenaan dengan waktu, tujuan, dan masa selanjutnya, mempelajari komponen-komponen kata dan kalimat, dan mengintegrasikan komponen katakata dan kalimat.

Membaca merupakan bagian dari empat keterampilan berbahasa yang harus dimiliki peserta didik. selain tiga keterampilan berbahasa lainnya yaitu berbicara, menyimak, dan menulis. Keterampilan membaca dinilai sangat penting dikuasai oleh siswa, karena dapat memberikan pengetahuan dan ilmu baru untuk siswa.

Tanda-tanda retardasi mental ringan mudah untuk diidentifikasi, jika orang tua serta guru mampu memerhatikan perkembangan anak dengan baik. Anak yang menderita retardasi mental ringan jika diberikan bahan bacaan yang tidak pernah dijumpai atai dibaca, anak akan membaca dengan tertatih-tatih, dengan pengucapan (fona) yang tidak jelas dan mereka akan membolak-balikkan kata satu dengan kata yang lainnya menjadi kalimat yang tidak jelas. Anak yang mengidap retardasi mental ringan memiliki gejala tidak mampu mengidentifikasi serta membedakan bunyi-bunyi dari apa yang dibicarakan oleh anak tersebut (Derek Wood, 2007:68).

Retardasi mental adalah istilah yang digunakan untuk menyebut anak yang mempunyai kemampuan intelektual dibawah rata-rata. Definisi anak retardasi mental menurut AAMR (American Assosiation on Mental Retardation) adalah sebagai berikut: "Retardasi mental adalah ketidakmampuan intelektual yang mengacu pada keterbatasan keberfungsian intelektual yang dicirikan dengan keberfungsian intelektual dibawah rata-rata, yang terjadi secara simultan dengan disertai keterbatasan di dua atau lebih area penyesuaian, pengaturan diri, kesehatan dan keamanan, fungsi akademik, rekreasi, dan pekerjaan.

Retardasi mental ringan dikategorikan sebagai retardasi mental dapat dididik (educable). Anak memiliki kesulitan berbahasa namun masih bisa memahaminya dalam kehidupan sehari-hari saat tanya jawab klinis. Secara tidak langsung anak atau siswa retardasi juga mampu mengurus diri sendiri yaitu terdiri saat anak makan, anak mencuci, dan memakai baju secara mandiri. Meskipun secara langsung dapat terlihat perkembangan tersebut sangat lamban dalam 
prosesnya jika dibandingkan dengan pola perkembangan anak normal. Hambatan yang paling menonjol saat anak mengikuti proses belajar mengajar di sekolah, dana memiliki perkembangan keterampilan membaca dan keterampilan menulis. Dalam konteks sosio kultural keterampilan pengetahuan dan keilmuan seharusnya tidak terlalu ditunjukkan, yang membuat anak tidak terbebani dalam berinteraksi. Namun berbeda ketika muncul permasalahan emosional dan interpersonal sosial maka anak akan menunjukkan perbedaan saat anak tidak mampu menguasai masalah interpersonal saat menjalin hubungan dengan orang lain atau penyesuaian dengan budaya sekitar.

Menurut

Lumbantobing (1997:85), pertumbuhan seorang anak dipengaruhi oleh retardasi mental ringan yang mampu diidentifikasi orang terdekat dengan perhatian. Meskipun pada perkembangannya anak dipengaruhi oleh faktor genetik dari orang tua sebagai pembawa gen awal atau gen bawaan serta lingkungan sekitar yang tidak dapat dipisahkan dari karakter anak. Yang dimaksud dengan lingkungan pada anak dalam konteks tumbuh kembang adalah suasana (milieu) dimana anak tersebut berada. Dalam hal ini lingkungan berfungsi sebagai penyedia kebutuhan dasar anak untuk tumbuh kembang. Asas kebutuhan anak dalam perkembangannya dapat digolongkan menjadi tiga golongan, yaitu:

1. Kebutuhan fisis-biomedis (asuh) : Pangan (gizi, merupakan kebutuhan paling penting), Perawatan kesehatan dasar (Imunisasi, ASI, penimbangan bayi secara teratur, pengobatan sederhana, dan lain lain), tempat (lingkungan tempat tinggal yang baik), bersih, pergantian udara, pakaian, pola pikir sehat, liburan atau traveling.

2. Kebutuhan kasih sayang saat pertama kali menjalin interaksi yang erat, dan saling mengisi antara ibu dan anak sebagai tujuan proses tumbuh kembang anak baik secara emosioanal, psikis, dan sosial.

3. Kebutuhan kebutuhan stimulus dalam hal ini adalah asah merupakan unsur awal proses memhami sistem pendidikan dan perlatihan untuk anak retardasi mental ringan. Pada perkembangan stimulus mental anak dapat belajar mandiri, sopan santun, dan lain sebagainnya. pengembangan keterampilan sosial seperti Perkembangan ini pada usia balita disebut sebagai perkembangan psikomotor.

Kelainan/penyimpangan tumbuh kembang pada anak terjadi karena kendala pertumbuhan sosial anak dengan lingkungan sekitar anak, sehingga kebutuhan yang mendasar dari perkembangan anak tidak mampu dicapai sebagai mana mestinya. Keadaan ini dapat menyebabkan morbiditas anak, bahkan dapat berakhir dengan kematian. Kalaupun kematian dapat diatasi, sebagian besar anak yang telah berhasil tetap hidup ini mengalami akibat menetap dari penyimpangan tersebut yang dikategorikan sebagai kecacatan, termasuk retardasi mental. Jelaslah bahwa dalam aspek pencegahan terjadinya retardasi mental praktek pengasuhan anak dan peran orangtua sangat penting (Payne, 1981: 466).

Melihat struktur masyarakat Indonesia, golongan sosio ekonomi rendah masih merupakan bagian yang besar dari penduduk, dapat 
diperkirakan bahwa retardasi mental di Indonesia yang terbanyak adalah tipe sosio-kultural.

Etiologi retardasi mental tipe klinis atau biologika dapat dibagi menjadi 3 yaitu:

1. Penyebab pranatal

a. Kelainan kromosom

Kelainan kromosom yang retardasi adalah gejala Down. Seorang anak yang baru lahir fisik dan penampilan berbeda menunjukkan kelainan mental dengan anak normal lainnya seperti autis. Penyebab ini tidak secara keseluruhan salah dan benar, karena beberapa penderita termasuk mengalami retardasi mental sedang. Sindrom Down merupakan 10-32\% dari penderita retardasi mental. Diperkirakan insidens dari sindrom Down antara 1-1,7 per 1000 kelahiran hidup per tahun. Penyebab timbulnya sindrom Down berhubungan dengan umur ibu saat mengandung dan melahirkan. Ibu yang berumur 20-25 tahun saat melahirkan berisiko 1:2000, sedangkan ibu yang berumur 45 tahun berisiko 1:30 untuk timbulnya sindrom Down. Analisis kromosom pada sindrom Down 95\% menunjukkan trisomi -21 , sedangkan $5 \% \quad$ sisanya merupakan mosaik dan translokasi (Prasadio, 1976: 162).

Kelainan kromosom lain yang bermanifestasi sebagai retardasi mental adalah trisomi18 atau sindrom Edward, dan trisomi-13 atau sindrom Patau, sindrom Cri-du-chat, sindrom Klinefelter, dan sindrom
Turner.

Berdasarkan pengamatan ternyata kromatin seks, yang merupakan kelebihan kromosom -X pada laki-laki lebih banyak ditemukan di antara penderita retardasi mental dibandingkan laki-laki normal. Diperkirakan kelebihan kromosom-X pada laki-laki memberi pengaruh tidak baik pada kesehatan jiwa, termasuk timbulnya psikosis, gangguan tingkah laku dan kriminalitas.

b. Kelainan metabolik

Kelainan metabolik berisiko muncul pada retardasi mental ringan ialah Phenylketonuria (PKU). Merupakan kendala metabolik saat fisik tubuh tidak bisa mengubah asam amino fenilalanin menjadi tirosin dikarenakan defisiensi enzim hidroksilase. Penderita laki-laki tenyata lebih besar dibandingkan perempuan dengan perbandingan 2:1. Kelainan ini diturunkan secara autosom resesif. Diperkirakan insidens PKUadalah 1:12 00015000 kelahiran hidup. Penderita retardasi mental pada PKU66,7\% tergolong retardasi mental berat dan $33,3 \%$ retardasi mental sedang (Prasadio, 1976: 188).

c. Infeksi

$$
\text { Menurut Prasadio }
$$

(1976:225), Infeksi rubela pada ibu hamil triwulan pertama dapat menimbulkan anomali pada janin yang dikandungnya. Risiko timbulnya kelainan pada janin berkurang bila infeksi timbul pada triwulan kedua dan ketiga. Manifestasi klinis rubela 
kongenital adalah berat lahir rendah, katarak, penyakit jantung bawaan, mikrosefali, dan retardasi mental.

Infeksi cytomegalovirus tidak menimbulkan gejala pada ibu hamil tetapi dapat memberi dampak serius pada janin yang dikandungnya. Manifestasi klinis antara lain hidrosefalus, kalsifikasi serebral, gangguan motorik, dan retardasi mental.

d. Intoksikasi

Fetal alcohol syndrome (FAS) merupakan suatu sindrom yang diakibatkan intoksikasi alkohol pada janin karena ibu hamil yang minum minuman yang mengandung alkohol, terutama pada triwulan pertama. Di negara Amerika Serikat FAS merupakan penyebab tersering dari retardasi mental setelah sindrom Down. Insidens FAS berkisar antara 1-3 kasus per 1000 kelahiran hidup. Pada populasi wanita peminum minuman keras insidens FAS sangat meningkat yaitu 21-83 kasus per 1000 kelahiran hidup, padahal di Eropa dan Amerika $8 \%$ wanita merupakan peminum minuman keras.

\section{Penyebab Perinatal}

Koch menulis bahwa 15$20 \%$ dari anak retardasi mental disebabkan karena prematuritas. Penelitian dengan 455 bayi dengan berat lahir $1250 \mathrm{~g}$ atau kurang menun-jukkan bahwa $85 \%$ dapat mempelihatkan perkembang-an fisis rata-rata, dan $90 \%$ memperlihatkan perkembangan mental rata-rata. Penelitian pada 73 bayi prematur dengan berat lahir
$1000 \mathrm{~g}$ atau kurang menunjukkan IQ yang bervariasi antara 59-142, dengan IQ rata-rata 94. Keadaan fisis anak-anak tersebut baik, kecuali beberapa yang mempunyai kelainan neurologis, dan gangguan mata. Penulis-penulis lain berpendapat bahwa semakin rendah berat lahirnya, semakin banyak kelainan yang dialami baik fisis maupun mental.

3. Penyebab Postnatal

Faktor-faktor postnatal seperti infeksi, trauma, malnutrisi, intoksikasi, kejang dapat menyebabkan kerusakan otak yang pada akhirnya menimbulkan retardasi mental.

Pendidikan inklusi adalah suatu kebijakan pemerintah yang mengusahakan sistem pendidikan yang dapat didapat oleh setiap putra bangsa agar memeroleh pendidikan yang layak tanpa memandang anak dengan kebutuhan khusus maupun umumnya supaya dapat pendidikan layak dengan jaminan lebih baik di masa depan kehidupannya.

Pendidikan inkusi pada setiap negara memiliki metode dan strategi yang berbeda-beda bergantung dengan kebutuhan lingkungan sekitar anak berkebutuhan khusus tersebut (Stubbs, 2002:200). Macam-macam penerapan metode dan strategi disebabkan budaya dan kebiasaan negara-negara tersebut, selain itu perbedaan juga terjadi pada tingkat provinsi, maupun kota.

Upaya memperkenalkan dan mengimplementasikan pendidikan inklusi di Indonesia telah dimulai sejak tahun 1980-an. Faktor-faktor yang memengaruhi keberhasilan dalam pendidikan inklusi ialah budaya, politik, sumber daya manusia yang di miliki (Kwon, 2005:57). index for inclusion ialah indek yang digunakan 
dalam mengukur pendidikan inklusi untuk evaluasi pendidikan di suatu daerah (Ainscow, 2000:286). Tiga dimensi yang memengaruhi adanya indeks inklusi, yaitu (1) dimensi Budaya (creating inclusive cultures), (2) dimensi Kebijakan (producing inclusive policies), dan (3) dimensi Praktik (evolving inclusive practices). Pasal 11 ayat 1 dan 2 tentang hak dan kewajiban pemerintah dan pemerintah daerah sebagai berikut: "Pemerintah dan pemerintah daerah wajib memberikan layanan dan kemudahan, serta menjamin terselenggaranya pendidikan yang bermutu bagi setiap warga negara tanpa diskriminasi”. "Pemerintah pusat dan pemerintah daerah wajib menjamin tersedianya dana guna terselenggaranya pendidikan bagi setiap warga negara yang berusia 7 -15 tahun".

Undang-Undang tersebut mampu menunjukkan untuk semua anak usia sekolah harus memperoleh pendidikan yang layak dan bermutu, serta pendidikan untuk semua (education for all). Kemajuan suatu bangsa dapat dilihat dari bagaimana proses pendidikan yang ada di dalamnya kemudian tertuang dalam kebijakan-kebijakan pemerintah yang diambil dalam penyelenggaraan pendidikan. Salah satunya adalah anak berkebutuhan khusus yang harus mendapat perlakuan sama dalam memperoleh pendidikan yang layak dan bermutu.

Dalam perkembangannya pendidikan anak berkebutuhan khusus telah banyak mengalami perubahan yaitu pada awalnya pendidikan anak berkebutuhan khusus bersifat segregasi atau terpisah dari masyarakat pada umumnya. Dalam pelaksanaan pendidikannya seperti sekolah SLB yang di dalamnya terdapat spesialisasi- spesialisasi terhadap anak berkebutuhan khusus sesuai dengan hambatanya seperti: SLB-A untuk sekolah anak tuna netra, SLB-B untuk sekolah anak tunarungu, SLB-C untuk sekolah anak tunagrahita, SLB-D untuk sekolah anak tunadaksa. Selanjutnya menuju pada pendidikan integratif, atau dikenal dengan pendekatan terpadu yang mengintegrasikan anak luar biasa masuk ke sekolah reguler, namun masih terbatas pada anak-anak yang mampu mengikuti kurikulum di sekolah tersebut dan kemudian inklusi yaitu konsep pendidikan yang tidak membedakan keragaman karakteristik individu.

Selama ini anak berkebutuhan khusus harus difasilitasi dengan pendidikan inklusi sebagaimana mestinya serta sesuai dengan kebutuhannya yang disebut dengan Sekolah Luar Biasa. Secara tidak langsung pendidikan yang seperti itu menciptakan tembok pembeda antara anak normal dan anak inklusi berkebutuhan khusus dengan anakanak pada umumnya. Hasil dari hal tersebut ialah hubungan sosial anak di masyarakat anak berkebutuhan khusus menjadi komunitas yang yang berbeda dari pertumbuhan sosial di masyarakat. Masyarakat menjadi tidak terbiasa karena adanya kelainan dengan anak berkebutuhan khusus. Sementara kelompok berkebutuhan khusus berpikir bahwa anak berkebutuhan khusus bukan bagian dari pertumbuhan sosial yang terhubung dari perbedaan di masyarakat dengan anak berkebutuhan khusus di sekitarnya.

Dinamika pertumbuhan penduduk yang dituntut dengan berbagai hal anak berkebutuhan khusus menyampaikan segala hak dan kewajibannya, sehingga dicetuskan pendidikan inklusi pada sistem 
pendidikan. Pada pasal 24 dalam Konvensi belajar mandiri, sopan santun, dan mental disebutkan bahwa setiap negara berkewajiban untuk menyelenggarakan sistem pendidikan inklusi di setiap tingkatan pendidikan. Adapun salah satu tujuannya adalah untuk mendorong terwujudnya partisipasi penuh kelompok berkebutuhan khusus dalam kehidupan masyarakat. Namun dalam prakteknya sistem pendidikan inklusi di Indonesia masih menyisakan persoalan tarik ulur antara pihak pemerintah dan praktisi pendidikan.

Meski sampai saat ini sekolah inklusi masih terus melakukan perbaikan dalam berbagai aspek, namun dilihat dari sisi idealnya sekolah inklusi merupakan sekolah yang ideal baik bagi anak dengan dan tanpa berkebutuhan khusus. Lingkungan yang tercipta sangat mendukung terhadap anak dengan berkebutuhan khusus, mereka dapat belajar dari interaksi spontan teman-teman sebayanya terutama dari aspek sosial dan emosional. Sedangkan bagi anak yang tidak berkebutuhan khusus memberi peluang kepada mereka untuk belajar berempati, bersikap membantu dan memiliki kepedulian. Disamping itu bukti lain yang ada mereka yang tanpa berkebutuhan khusus memiliki prestasi yang baik tanpa merasa terganggu sedikitpun.

Penyelenggaraan sistem

sekolah inklusi merupakan salah satu syarat yang harus terpenuhi untuk membangun masyarakat inklusi. Sebuah tatanan masyarakat yang saling menghormati dan menjunjung tinggi nilai-nilai keberagaman sebagai realitas kehidupan. Banyak kasus yang muncul terkait pelaksanaan pendidikan inklusi, seperti minimnya sarana penunjang sistem pendidikan inklusi, terbatasnya pengetahuan dan keterampilan yang dimiliki oleh para guru sekolah inklusi menunjukkan bahwa sistem pendidikan inklusi belum dipersiapkan dengan baik.

Penyelenggaraan sekolah inklusi untuk ABK atau anak berkebutuhan khusus khusunya retardasi harus memunculkan kondisi yang mampu mendukung pembelajaran untuk anak dengan kebutuhan khusus, dan suasana belajar yang diciptakan harus mampu mewadahi segala kemungkinanan kebutuhan dan tujuan pembelajaran dari anak. Dibentuknya pendidikan inklusi memang tidak semudah menyelenggarakan sekolah formal pada umumnya. Segala hal yang terjadi dilapangan dan berkaitan dengan pendidikan inklusi belum sesuai atau selaras dengan kebijakan pendidikan di Indonesia, tingkat pemahaman dan kecerdasan siswa ABK tidak bisa disamakan dengan anaka normal lainnya. Karena anak ABK memiliki kriteria pemahaman sendiri dalam konteks yang sama namun kecepatan pemahaman yang berbeda. Dalam hal penerimaan jumlah siswa juga memiliki batas atau kuota dalam penerimaan siswa. Hal tersebut berpengaruh pada pembelajaran langsung ketika di kelas. Jumlah siswa yang dibatasi juga harus didukung dengan sarana dan prasarana yang mendukung dalam pembelajaran di kelas. Peran orang tua dalam pembelajaran anak dengan kebutuhan khusus juga harus mendukung dalam setiap perkembangan anak dengan kebutuhan khusus yang berbeda-beda dengan kriteria yang berbeda pula. Selain dukungan moral dukungan material dari orang tua juga harus diberikan secara konsisten dan terus 
menerus, selain itu dukungan peran aktif orangtua dalam keterlibatan kegiatan belajar mengajar juga dibutuhkan secara langsung ketika kegiatan belajar berlangsung. Selain dukungan orangtua anak secara penuh, perlu adanya dukungan pemerintah pusat dan daerah dalam upaya pendidikan inklusi. Meskipun diketahui kebijakan pemerintah belum mampu mencakup secara menyeluruh jika didasarkan pada kebutuhan anak inklusi. Dukungan tersebut bisa berupa teknis pelaksanaan penyelenggaraan mulai dari keterlibatan dalam pelaksanaan, monitoring, bimbingan dengan evaluasi pelaksanaan pendidikan inklusi. Dan bantuan non teknis yang berupa dana dan sarana dan prasarana.

\section{METODE}

Penelitian ini adalah penelitian kualitatif jenis studi kasus. Studi kasus dalam penelitian ini adalah satu kasus, studi kasus tersebut harus menampakkan kasus-kasus ekstrem atau tidak biasa. Psikologi klinis yang menggambarkan suatu permasalahan seperti kecacatan yang spesifik dan tidak biasa bahkan bisa disebut langka, bahkan selalu menjadi menarik untuk dibahas dan dipelajari dalam keilmiahan.

Menurut Yin (1995:47-49). penelitian studi kasus merupakan suatu desain yang cocok untuk beberapa keadaan. Pertama, satu studi kasus yang banyak memiliki kondisi yang muncul bersamaan bisa dijadikan studi kasus tunggal atau kasus analog dengan satu eksperimen saja. Karenanya, sebuah rasional untuk satu kasus ialah manakala teori yang diuji dan disusun dengan baik harus mampu menyatakan kasus tersebut layak untuk dipelajari.
Subjek penelitian ini adalah satu siswa (VK) dari kelas 5 SDI Yaspai.

\section{HASIL DAN PEMBAHASAN Aktivitas siswa VK dalam memeroleh Konsonan, Vokal, Diftong, dan Kata}

Aktivitas siswa VK saat mempelajari Pada observasi fona ada tiga kriteria yang diamati yaitu, vokal, diftong, dan konsonan. Pada vokal perilaku yang diamati menunjukkan bahwa anak tidak dapat membaca dengan vokal tinggi, anak hanya dapat membaca dengan vokal rendah sampai sedang saja.

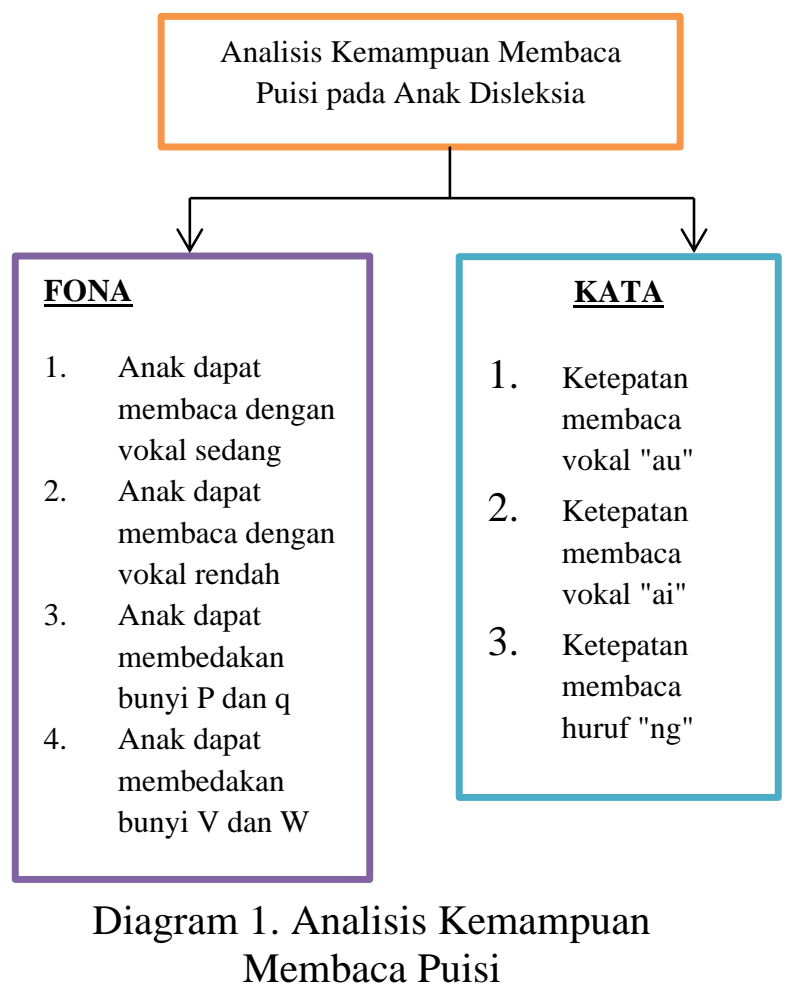

Sedangkan pada diftong yang diamati menunjukkan bahwa anak mampu dalam membaca diftong /ai/, ditunjukkan pada bait ke empat puisi pada kata bagai. Dan anak juga mampu membaca diftong /au/ yang di buktikan pada kata surau, engkau, tau. Pada bait ke satu, dua, dan tiga. 
Dan pada konsonan yang diamati, menunjukkan bahwa anak tidak dapat membedakan bunyi /b/ dan /d/, di buktikan pada kata pengabdianmu. Anak membacanya dengan kata peabbiammu. Anak tidak dapat membedakan bunyi /l/dan /r/, di buktikan pada kata rela. Anak membacanya dengan kata lela. Anak juga tidak dapat membedakan bunyi $/ \mathrm{m} /$ dan /n/, di buktikan pada kata pengabdianmu. Anak membacanya dengan kata peabbiammu. Namun Anak dapat membedakan bunyi /p/dan /q/, di buktikan pada kata pelita. Anak membacanya dengan baik dan benar. Dan juga Anak dapat membedakan bunyi /v/ dan /w/, di buktikan pada kata waktu. Anak membacanya dengan baik dan benar.

Dapat disimpulkan bahwa pada observasi fona yang di lakukan, menunjukkan bahwa yang pertama, anak hanya dapat membaca dengan vokal rendah sampai sedang saja. Yang kedua, anak dapat membaca diftong /ai/ dan /au/ dengan benar, namun hanya pada dua suku saja, berbeda dengan yang mempunyai beberapa suku kata, anak tidak dapat membacanya dengan benar. Yang ketiga, pada observasi konsonan yang dilakukan peneliti terhadap anak retardasi mental ringan menunjukkan bahwa anak retardasi mental ringan yang peneliti observasi, tidak dapat membedakan bunyi huruf /b/ dengan /d/, /l/ dengan $/ \mathrm{r} /$, dan $/ \mathrm{m} /$ dengan $/ \mathrm{n} /$. Namun anak retardasi mental ringan dapat membedakan bunyi huruf /p/ dengan /q/, dan /v/ dengan $/ \mathrm{w} /$.

Sedangkan pada observasi kata perilaku yang diamati dalam ketepatan membaca vokal /au/, anak mampu membacanya, di buktikan pada kata surau pada bait pertama puisi Sang
Pelita. Ketepatan membaca vokal /ai/, anak mampu membacanya, di buktikan pada bait puisi ke empat pada kata bagai. Ketepatan membaca huruf /ng/, anak mampu membacanya, dibuktikan pada bait ke dua yaitu pada kata sering. Ketepatan membaca huruf /ny/, anak belum bisa membacanya, dibuktikan pada kata hanya di bait ke dua, anak membaca kata hanya dengan kata hana.

Ketepatan anak membaca dengan pola KVK (Konsonan-VokalKonsonan), anak tidak bisa, atau anak belum mampu membacanya, dibuktikan pada kata Tanpamu pada bait puisi pertama, anak membaca mengeja dengan salah, yang seharusnya kata Tапрати menjadi kata Тарати. Ketepatan membaca dengan pola VKK (Vokal-Konsonan-Konsonan), anak tidak bisa, atau anak belum mampu membacanya, dibuktikan pada kata Engkau, bait puisi ke dua, anak membaca kata Engkau, menjadi kata Ekau. Ketepatan membaca dengan pola KVKK (Konsonan-Vokal-KonsonanKonsonan) anak tidak bisa, atau anak belum mampu membacanya, dibuktikan pada kata Menyinari di bait ke empat puisi, anak membaca kata Menyinari dengan bacaan Meninari.

Ketepatan membaca 4 suku kata /au/. Pada ketepatan membaca 4 suku kata /au/ dan /ng/ anak tidak bisa, atau anak belum mampu membacanya, dibuktikan pada kata terbengkalau, pada bait puisi pertama, anak membaca kata Terbengkalau menjadi kata terbekala. Ketepatan membaca 4 suku kata /ny/, anak tidak bisa atau belum mampu membaca kata menyayangi, pada bait puisi ke tiga, anak membaca kata menyayangi menjadi kata meyayagi. 


\section{PENUTUP Simpulan}

Anak retardasi mental ringan (VK) hanya dapat memenuhi beberapa kriteria dalam fona. Hal ini dapat dilihat dari hasil observasi fona yang menunjukkan bahwa dalam tiga kriteria yang diamati yaitu, Vokal, Diftong, dan Konsonan, anak hanya dapat membaca dengan vokal rendah sampai sedang saja. Yang kedua, anak (VK) dapat membaca diftong /ai/ dan /au/ dengan benar, namun hanya pada dua suku kata saja, berbeda dengan yang mempunyai beberapa suku kata, anak tidak dapat membacanya dengan benar. Yang ketiga, anak tidak dapat membedakan bunyi huruf /b/ dengan /d/, /l/ dengan $/ \mathrm{r} /$, dan $/ \mathrm{m} /$ dengan $/ \mathrm{n} /$. Namun anak retardasi mental ringan dapat membedakan bunyi huruf /p/ dengan /q/, dan /v/ dengan /w/.

Anak retardasi mental ringan (VK) hanya dapat memenuhi beberapa kriteria dalam kata. Hal ini dapat dilihat dari hasil observasi kata yang menunjukkan bahwa anak dapat membaca vokal /au/, ai/, dan huruf /ng/ dengan benar, namun hanya pada dua suku kata saja, berbeda dengan kata yang mempunyai 4 suku kata atau lebih, anak masih salah dalam membaca huruf- huruf tersebut. Pada saat anak membaca huruf /ny/ juga anak belum mampu dalam membacanya dengan benar, walau hanya dua suku kata. Dan pada membaca yang mempunyai pola seperti (KVK), (VKK), dan (KVKK), anak juga belum mampu membacanya dengan benar.

\section{Saran}

Saran dalam penelitian ini adalah kemampuan membaca puisi pada anak retardasi mental ringan, bahwa orang tua, guru, maupun keluarga untuk anak dengan retardasi ringan harus memiliki dukungan secara terus-menerus demi perkembangan anak retardasi mental ringan.

\section{DAFTAR PUSTAKA}

Abdurrahman, Mulyono. (2009). Pendidikan Bagi Anak Berkesulitan Belajar. Jakarta: PT Rineka Cipta.

Akhmad Sudrajat. (2008). Pengertian Pendekatan, Strategi, Metode, Teknik dan Model Pembelajaran. Bandung: Sinar Baru Algensindo.

Alwasilah, A. Chaedar. (1985). Sosiologi Bahasa. Bandung: Angkasa.

Alwi, Hasan. (1988). Tata Bahasa Baku Bahasa Indonesia. Jakarta: Balai Pustaka.

Aminuddin. (2003). Semantik Pengantar Studi Tentang Makna. Bandung: Sinar Baru Algensindo.

Chaer, Abdul. (2008). Linguistik Umum. Jakarta: PT. Rineka Cipta.

Creswell, J. W. (2016). Research design: pendekatan kualitatif, kuantitatif, dan mixed. Yogjakarta: PT Pustaka Pelajar.

Dardjowidjojo, Soedjono. (2003). Psikolinguistik: Pemahaman Bahasa Manusia. Jakarta: Yayasan Obor Indonesia

Das, J.P. (2009). Reading Difficulties And Dyslexia. New Delhi: Chaman Enterprises.

Departemen Pendidikan Nasional. (2015). Kamus Besar Bahasa 
Indonesia. Edisi Keempat. Jakarta: Gramedia Pustaka Utama.

Derek Wood, dkk. (2007). Kiat Mengatasi Gangguan Belajar. Jogjakarta: Kata Hati.

Djajasusarma T. Fatimah. (1993). Semantikl Pengantar Ke Arah Ilmu Makna. Bandung: Pteresco.

Hornby, A.S. Sixth edition. (2003). Oxford Advanced Learner's Dictionary of Current English. Oxford: Oxford University Press.

Jamaris, Martini. (2014). Kesulitan Belajar: Perspektif, Asesmen, dan Penanggulangannya. Bogor: Ghalia Indonesia.

Keraf, Gorys. (1980). Tata Bahasa Indonesia. Jakarta: Nusantara

Kridalaksana Harimuri. (1992). Pembentuk Kata dalam Bahasa Indonesia. Jakarta: Gramedia Pustaka Utama.

Kridalaksana, Harimurti. (2015). Introduction to Word Formation and Word Classes in Indonesian. Jakarta: Yayasan Pustaka Obor.

Lumbantobing SM. (1997). Anak dengan mental terbelakang. Jakarta: Balai Penerbit FKUI.

Michail, Konstantina. (2010). The Experiences of University Students with Dyslexia. Disertasi tidak diterbitkan. Brimingham: University of Brimingham.
Mustofa, I. (2004). Identifikasi Letak Kesalahan Dalam Menyelesaikan Soal Cerita Operasi Hitung Bilangan Pecahan Siswa Kelas V SD Negeri II Sumberagung. Surabaya: Unesa.

Mulyadi. (2015). Diagnosis Kesulitan Belajar \& Bimbingan terhadap Kesulitan Belajar. Yogyakarta: Nuha Litera.

Moleong, Lexy J. (2009). Metode Penelitian Kualitatif. Edisi Revisi. Bandung: PT. Remaja Rosdakarya.

Nurhadi. (2005). Bagaimana Meningkatkan Kemampuan Membaca?. Bandung: Sinar Baru Alennsindo.

Nurhayati, Eni (2020). Analisis Kemampuan Berbahasa Mahasiswa Disleksia Sebagai Calon Guru Sekolah Dasar Studi Kasus (Na). Kudus:Universitas Muria Kudus

Payne JS. (1981). Mental retardation. Columbus: Bell \& Howell Company.

Prasadio T. (1976). Gangguan psikiatrik pada anak-anak dengan retardasi mental. Disertasi. Surabaya: Universitas Airlangga.

Rahmad Jalaluddin. (2008). Metode Penelitian Komunikasi. Bandung: Remaja Rosda

Razak, Abdul. (2000). Membaca Pemahaman Teori dan Aplikasi Pengajaran. Pekanbaru: Autografika. 
Ritawati. (2005). Modul Belajar Mandiri Program D II PGSD. Jakarta: Pustekom Depdiknas.

Ridwan Idris. (2009). Mengatasi Kesulitan Belajar Dengan Pendekatan Psikologi Kognitif. Bandung: Lentera Pendidikan.

Sahriah, S. (2010). Analisis Kesalahan Siswa Dalam Menyelesaikan Soal Matematika Operasi Pecahan Bentuk Aljabar Kelas VII SMP Negeri 2 Malang.

Samsuri. (1994). Analisis Bahasa. Jakarta: Erlangga.

Santoso Puji, dkk. (2007). Materi dan Pembelajaran Bahasa Indonesia SD. Jakarta: Universitas Terbuka.
Sugiyono (2015). Metodem Penelitian Kombinasi (Mix Methods). Bandung: Alfabeta.

Tarigan, Henry Guntur. (1986). Pengajaran Semantik. Bandung: Angkasa.

Verhaar, J.W.M. (1984). Pengantar Linguistik.Yogyakarta: Universitas Gadjah Mada.

Yin, R.K. (1995). Studi Kasus Desain dan Metode. Jakarta: PT Raja Grafindo Persada.

Zuchdi, Darmiyati dan Budiasih. (1996). Penddiikan Bahasa dan Sastra Indonesia di Kelas Rendah. Jakarta: Depdikbud. 